\title{
Media Use Preference: The Mediating Role of Communication on Political Engagement
}

\author{
Kyungmee Park ${ }^{1}$ and Sukkyung You ${ }^{2}$ \\ ${ }^{1}$ Chonbuk National University, Jeonju, Korea \\ ${ }^{2}$ Hankuk University of Foreign Studies, Seoul, Korea
}

\begin{abstract}
$\mathrm{T}$ his study examined the impact of media use on political engagement among South Korean voters. The two major strengths of the current study were the examination of multiple dimensions of media use and citizen communication, and the consideration of mediating variables. Multigroup structural equation modelling was used to examine the direct and indirect effects of media use on political engagement via mediator online citizen communication. The present study used data from the 19th General Election Survey in Korea conducted by the Korean Social Data Center. A nationally representative sample of 829 Korean voters (age range: 21-59) was included for analysis. Results indicated: (1) for those in the 20-30 year age group, political efficacy positively predicted online media use and this, in turn, was related to political engagement via mediator online citizen communication; and (2) for those in the 40-50 year age group, political efficacy positively predicted both offline and online media use, with online media use affecting political engagement directly.
\end{abstract}

Keywords: offline media, online media, citizen communication, political engagement, political efficacy

Various media use promoted by technological advances has changed how people communicate. The introduction of new types of online media has reduced psychological distance among people who are geographically far from one other, and has made communication among people more immediate and interactive. However, online media has also widened the gap of political information available between people who use online media and those who do not. Those who are familiar with online media can obtain more diverse information through this source than those who use offline media. The digital divide that stemmed from the popularisation of the internet is now being replicated in the form of social media divides between its users and non-users (Jaeger, Bertot, \& Shilton, 2012). One can anticipate the effects of rapid media development on media use preference and political engagement as well. Media use preferences can differ depending on the media circumstance when people are of secondary school age. People who have lived primarily utilising offline media may feel more comfortable communicating offline, whereas those who experienced a digitalised education system may be accustomed to using online media. How these differences in utilising media affect political engagement is in need of investigation, to confirm whether those familiar with online media will feel more at ease with establishing their political stance online, and whether those who are not familiar with online media find it more effective to establish their political position through direct communication with others offline. It might lead to diverse political engagement when social issues emerge.

From this perspective, this study aims to examine differences in the use of online/offline media communication for political engagement, particularly between two generational groups of Korean adults. The main interest is whether uses of and communication through media change political engagement: How do the two groups differ in their use of online and offline media and does their communication through online and offline media affect their political engagement? The specific research questions are as follows: Does online media use and communication change the basic orientation of people towards political engagement? Does online media use and communication enhance political engagement more than offline media use, regardless of individual political efficacy for political engagement? Does online media use and communication within the the younger generation have a stronger effect on their political engagement than that of the older generation who were socialised in circumstances when online media were not universal? 
Differences in the types of media people use and communicate with are not simply an issue of individual preference. The fast development of technologies may have an effect on how people communicate with others increasing the opportunities to show their opinions. With political engagement considered an essential element for the development of a stable democracy (Huntington, 1968), and people gaining more opportunities to take a stance and act politically with one another, we need to identify the effects of media use on political engagement for long-term societal development.

\section{Political Context of Korean Generation Groups}

Korea is a unique space to examine the impact of online media. Korea has been identified as the most 'wired' country in the world, with $82.7 \%$ internet penetration (Cha, 2013). Economic strategies that have concentrated on internet industries as one of the solutions to recover from the 1997 economic recession has stimulated the technical development and uses of online media, such as electronic commerce, e-government, and social media. The explosive spread of the internet and the ease of access to online media over the past two decades have most likely contributed to changing the way members of Korean society communicate: from direct contact and face-to-face meetings to immediate online interactions.

The invigoration of online media seems to have been a turning point to divide members of society into two distinctive generational groups. One of the two groups in this study was made up of individuals in their forties and fifties, called the ' 4050 generation'. They share experiences and memories of significant political changes. This group, who were born in the 1960s or 1970s and were students of college or high school in the 1980s, participated directly and indirectly in extensive anti-oppressive government demonstrations that led to the democratisation of the country in 1987 . They assembled through phone calls, materials sent through the postal service, and face-to-face meetings.

In contrast, the '2030 generation' is made up of individuals who are currently in their twenties and thirties and share economic and cultural experiences that grew out of the 4050 generation's political experiences. This 2030 generational group was educated during the 1997 Asian economic recession and spent their stormy period of adolescence during the economic turbulence thath originated from the U.S. subprime mortgage crisis. They are the ones most heavily affected by the unemployment and job instability that has existed in the economic market since the mid 2000s. Culturally, this age group actively experienced the various nationwide candlelight vigils held to express solidarity, such as that in 2002 to show anti-American sentiment and in 2008 to demand a renegotiation on the Korea-U.S. Free Trade Agreement. This generation also enjoyed being young adults when the country cohosted the 2002 World Cup with Japan. Online media (such as blogs, websites) gave them opportunities to gather information and run out into the streets in protest whenever social issues emerged.

Differences between the two groups in interacting with media technologies is more evident nowadays. For example, during the 2010 local election, when photos of celebrities sharing that they had participated in voting appeared on social media, the polls saw an increase in voter turnout among younger adults. This was dubbed the 'Twitter politics' of the younger generation (Asia Today, 2011). Many politicians and political parties are attempting to utilise social media to increase the participation of those who fall into the 2030 generation. Also, the National Election Commission made advertisements with teen-idol stars to heighten the low voting rates of those in their twenties and thirties.

\section{Media Uses and Political Engagement}

Currently, political engagement is an interchangeable term with political participation, since voting during regular elections is a typical form of political participation (Ansolabehere, Iyengar, Simon, \& Valentino, 1994; Berelson, Lazarsfeld, \& McPhee, 1954). However, technological advances have widened the scope of political engagement. Online media allows people to become involved in social issues or other political things easily and quickly. Individuals and organisations worldwide can get in touch with politicians, parties or any institution, gather information, declare their own opinions, and make contact with others through online media more immediately (Bennett, 2012; de Zúñiga \& Valenzuela, 2011; Tolbert \& McNeal, 2003; Xenos \& Moy, 2007).

Previous studies showed that media use contributes to political engagement positively (Jung, Kim, \& de Zúñiga, 2011; Schmitt-Beck, 2003; Shah et al., 2007; Sotirovic \& McLeod, 2001; Tian, 2011; Willnat, Wong, Tamam, \& Annette, 2013). Voting, a typical form of political engagement, requires political information related to whether and how much a certain party or candidate is close to voters' own stances (Downs, 1957). Ease of access to much more information through the use of new online media contributes to increased political engagement, due to reducing the individual cost to get information.

Complicating this relationship, previous studies that investigated the effects of online media use found differences among individuals' characteristics and style of communication (Bimber, 2001; Bennett, 2012; Ikeda \& Boase, 2011). Online communication is associated with online political participation (Valenzuela, Kim, \& de Zúñiga, 2012), and the influence online communication has on political engagement is stronger than that between offline communication and political engagement (de Zúñiga \& Valenzuela, 2011). Based on this, we anticipated that the more actively people engage in online communication, where they share their own opinions and observe and 
react to others' opinions, the more politically engaged they will be.

Further, does online media use and communication change the basic orientation of people towards political engagement? Does online media use have stronger effects on political engagement than offline media use, regardless of individuals' orientation for political engagement? To answer these questions, we need to consider political efficacy as an internal psychological factor for political engagement. Political efficacy - that is, feeling capable of influencing the political decision-making process - is understood as an acceleration factor of political engagement (Campbell et al., 1954; Milbrath \& Goel, 1977). That is, the higher political efficacy is, the more positively people try to engage in political affairs.

However, the effect of political efficacy on political engagement can be mediated by media use and communication because information acquisition may change people's attitudes to political engagement. A higher level of political efficacy motivates the use of media to gather political information, which is a factor in increased interest in political engagement (Miller, Miller, \& Schneider, 1980; Verba, Schlozman, \& Brady, 1995). In socialisation, most people form patterns of information acquisition as well as political efficacy (Semetko \& Valkenburg, 1998), but the effect of political efficacy on political engagement can be differentiated depending on how information is obtained from media use and communication. Frequent media use promotes political engagement, and online communication is studied as a significant predictor of voting, especially among younger generations (Moeller, de Vresse, Esser, \& Kunx, 2013). Supposing that internalised political efficacy is seldom changed, different media circumstances of the socialisation process can change media use and information acquisition patterns, which can differentiate the effect of media use on political engagement among age groups.

If that is the case, does online media use and communication utilised by the younger generation have stronger effects on their political engagement than that of the older generation who were socialised in circumstances when online media was not universal? Although there is a controversy over whether differences of age groups in political engagement comes from a cohort effect or a period effect, conventional wisdom says that the younger generation is less interested in politics than older generations (cf. Henn, Weinstein, \& Wring, 2002; Hooghe, 2004). Another way of putting this into perspective is that the older generation is more engaged in politics. Although age cannot be separated from political experience, as in people being exposed to more experiences as they age, ageing is a powerful factor to explain offline active participation (Watts, 1999).

However, age differences in online political engagement can be different from offline political engagement because online political engagement is relatively free from financial constraints and external pressures, especially for the young generation (Barnhurst, 2011; Jugert, Eckstein, Noack, Kuhn, \& Benbow, 2013). For the younger age group who is willing to pay the low cost of online media, their higher online political engagement can be anticipated. In the same vein, a report by the Pew Research Center showed that younger social media users are more likely to exhibit online political engagement behaviours (Pew Research Center, 2012). Most online activists in the United States are part of the younger generation aged under 35 years old and are less active in offline political participation (Oser, Hooghe, \& Marien, 2013). Thus, a new trend of political engagement and a generational shift in public realm are predicted when the younger generation, called 'digital natives', familiar with online communication, enter the electorate (Ferri, 2012; Xenos \& Moy, 2007).

Research questions of this study echo previous studies in Asia. According to a comparative study on Asian and African countries, the frequencies of online media use promote expressions of democratic demands (Nisbet, Stoycheff, \& Pearce, 2012). Also, a study in China shows that the effect of media use and communication can be explained by individual cultural orientation linked to online behaviours such as the style, content, and expressed values of online debates (Ye, Sarrica, \& Fortunati, 2014). The younger generation, a group with increased exposure and application in online media, can be more expressive than the older generation, who have possibly less experience with online media. In this vein, we need to pay attention to the case in Hong Kong in which the younger generation did not show markedly different characteristics in online media use, which means that assumptions about generational differences in online media use is a topic that needs to be explored (Chu, 2010).

From this perspective, the current research examined whether political efficacy can explain different uses of various online/offline media, and whether this, in turn, results in different levels of political engagement. Furthermore, patterns of such relations in different age groups are explored. Considering the context of South Korea, one would expect that the 4050 generation, compared to the 2030 generation, would have higher political efficacy due to their experiences of the collective movements that would encourage more active political engagement. Also, one might expect media use and communication to have more positive effects on political engagement among the 2030 generation, who are more familiar with the use and means of communication of online media than the 4050 generation.

\section{Hypothesised Model}

To investigate these differences between generational groups, this study aimed to test the model presented in Figure 1. The hypothesised model represents the examination of relationships between political efficacy, offline and online media use, communication, and political engagement. It was hypothesised that the relationships between both offline and online media use would be positively related to political engagement both directly and indirectly 


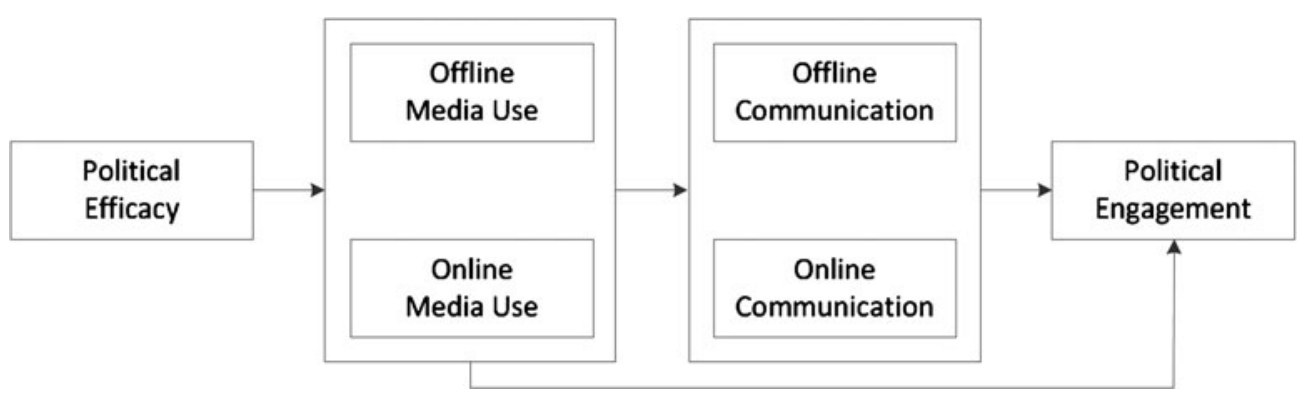

\section{Figure 1}

Hypothesised model of political efficacy, media use, citizen communication, and political engagement.

via mediating variables (i.e., offline and online communication). Based on previous studies (Bimber, 2001; Bennett, 2012; Valenzuela et al., 2012), offline and online communication were tested as mediating variables between media use and political engagement.

\section{Measures}

\section{Political engagement}

Political engagement initially referred to voting in regular elections (Ansolabehere et al., 1994; Berelson et al., 1954). The concept has further expanded to include various other political activities as well (Verba et al., 1995). In this study, political engagement included participation in five activities: voting, signing petitions, participating in social movements, participating in legal demonstrations, and joining political parties/civic associations. Among the five types of political engagement, the more direct type of political engagement is joining political parties and civic associations. Participating in these activities is distinctive in terms of the inclusive purpose and persistency of the behaviour, which requires a higher level of volunteerism than the other types of political engagement. Not only should one have an active and consistent interest in social issues to participate in social movements, but it can also lead to related communal activities in the long term.

The remaining four activities shared two characteristics. First, those activities are one-time events. Elections are only held during set periods. Social movements and demonstrations may not persist long enough, depending upon the introduction and decline of the social issues to which they are responding. Second, these activities require a high level of interest in social issues and voluntarism for individuals' direct intervention. Individuals who become involved are motivated by the possibility of affecting electoral results and political processes. The reliability coefficient using Cronbach's alpha coefficient for this scale was .72 .

\section{Political efficacy}

An important individual psychological factor for understanding political engagement is political efficacy. Political efficacy is defined as 'the feeling that political and social change is possible, and that the individual citizen can play a part in bringing about this change' (Campbell et al., 1954, 188p.). Specifically, one's internal political efficacy, which refers to the subjective belief about one's own ability to affect politicians' policy decision, influences political engagement (Miller et al., 1980; Verba et al., 1995). In other words, people with high political efficacy believe it is possible to change political systems, and thus they become actively involved in politics.

Political efficacy was measured using four items (e.g., who people vote for makes a difference). This scale was rated on a 5-point Likert scale scored from 1 (strongly disagree) to 5 (strongly agree). Items were coded so that higher scores indicate a higher sense of political efficacy. The reliability coefficient using Cronbach's alpha coefficient for this scale was .77.

\section{Media use}

Media use was measured by eight items. Respondents were asked to rate on a 4-point scale from 1 (not at all) to 4 (very frequently) how often they used the following media to get information about election and political issues: offline media (e.g., print newspapers, print news magazines) and online media (e.g., online newspapers, online news magazines). The items were coded, so that a higher number indicated more news consumption. The reliability coefficient using Cronbach's alpha coefficients for this scale was .74 and .76, for offline and online media use, respectively.

\section{Citizen communication}

Citizen communication was measured by 10 items. The respondents were asked to indicate, by means of a fourpoint scale from 1 (not at all) to 4 (very frequently), how frequently they discussed political issues (e.g., elections, voting, political parties) during an election period, either offline (face to face) or online. The reliability coefficient using Cronbach's alpha coefficients for this scale was .92 and .79 for offline and online communication respectively.

\section{Data and Statistical Analysis}

This study investigated the relationship between political efficacy, media use and communication, and political engagement using data drawn from the 19th General Election Survey in Korea, conducted by Korean Social Data 
Center and funded by the National Election Commission of Korea. We selected this data because it has diverse questionnaires on voters' political behaviours and media use, and thus we could identify various routes for political information and diverse types of political engagements around electoral periods.

This survey was administered through face-to-face interviews from April 12 to April 23, right after the 19th general election of April 11, 2012. It included 1,000 respondents who were 19 years and older in 16 metropolitan areas and major cities. It closely approximates national demographic benchmarks. Respondents were randomly selected using stratifications based on gender, age, and region from residents who were registered to the Korean Statistical Information Service. Among the total sample, the mean age was 44.15 years $(S D=15.29$ years, range 19-90 years). The gender distribution was $49.6 \%$ males and $50.4 \%$ females. There were $2.2 \%$ upper class $(80-100$ percentile), $11.7 \%$ upper middle class (60-80 percentile), $45.4 \%$ middle class (40-60 percentile), $28.7 \%$ lower middle class (60-80 percentile), and $12.1 \%$ lower class (60-80 percentile). Response rates of study variables ranged from $97.8 \%$ to $99.8 \%$.

The composition of the two generational subgroups was as follows: the gender distribution was $51.5 \%$ females and $48.5 \%$ males for the 2030 and 4050 generations, respectively. Regarding socioeconomic status, the distribution was $1.9 \%$ and $3.1 \%$ upper class ( $80-100$ percentile), $12.3 \%$ and $12.4 \%$ upper middle class (60-80 percentile), $51.8 \%$ and $44.7 \%$ middle class ( $40-60$ percentile), 26.2 $\%$ and $27.6 \%$ lower middle class (60-80 percentile), and $7.8 \%$ and $12.1 \%$ lower class (60-80 percentile) for the 2030 and 4050 generations, respectively.

Participants were deliberately separated into two age groups for comparison. One group came of voting age before the mid-1990s and was referred to as the 4050 generation since they are currently in their forties and fifties. The other group that reached voting age after the mid1990s was referred to as the 2030 generation, since they are currently in their twenties and thirties. In addition to the different political and societal environments these two age groups experienced as young adults, the assumption was that the older 4050 generation was not as accustomed to the internet and social media because they had to learn the technology as adults. In contrast, the assumption was that those in their twenties and thirties were younger when they were exposed to the internet and social media and thus were expected to be more familiar with the technology.

\section{Demographic Variables}

Studies have suggested that family socioeconomic status level is associated with the degree of political engagement (Bachmann, Kaufhold, Lewis, \& de Zúñiga, 2010; Brady, Verba, \& Schlozman, 1995; Rosenstone \& Hansen, 1993; Verba \& Nie, 1972). Voters with a higher educational level have higher rates of political engagement (Blais
\& Dobrynska, 1998; Wolfinger \& Rosenstone, 1980). Therefore, family income and educational level were also included in the study as control variables.

\section{Statistical Analysis}

We used structural equation modeling (SEM) to assess the hypothesised structural relationships among latent variables. SEM was selected because it is an appropriate analytic approach to specify directionality among variables of interest and generate flexibility to test causal relationships. Specifically, this study conducted an evaluation of the hypothesized model of the relationships among political efficacy, offline and online media use, communication, and political engagement. In addition, two mediational models were tested as a comparison to derive the best model. To test the significance of the mediating effects, we conducted bootstrapping methods, outlined by Shrout and Bolger (2002).

In general, chi-square goodness-of-fit tests are known to be sensitive to sample size, particularly when the sample size is large (Steenkamp \& Baumgartner, 1998). In these cases, the null hypothesis may be rejected and the model that should be determined statistically inadequate may be ruled adequate. Therefore, we decided to assess the model fit based on several other criteria. Specifically, we used the non-normed fit index (NNFI; Bentler \& Bonett, 1980), comparative fit index (CFI; Bentler, 1990), and root mean square error of approximation (RMSEA; Steiger \& Lind, 1980). Values lower than .08 for the RMSEA and values close to .95 for the NNFI and CFI were used to determine a good-fitting model. All analyses were conducted using Mplus 7.11 (Muthén \& Muthén, 2010).

\section{Results}

\section{General Findings Based On Age Groups}

$T$ tests were conducted to see if there are group differences regarding the variables of interest (see Table 1). There was a significant difference in both kinds of media use, with the 2030 generation reporting stronger preferences for online media use, while the 4050 generation reporting stronger preferences for offline media use. With regard to citizen communication, there were significant group differences using offline means. The 4050 generation reported stronger preferences for offline communication compared to the 2030 generation. Lastly, group differences were found in political engagement. The 2030 generation reported greater engagement in social movements and demonstrations compared to the 4050 generation, while the 4050 generation reported higher voting rates compared to the 2030 generation. Significant correlations were found among the study variables in both groups (see Table 2). The 2030 generation reported political efficacy only being related to offline communication. For the 4050 generation, political efficacy was related to both online and offline communication. 


\begin{tabular}{|c|c|c|c|c|c|c|}
\hline \multirow[b]{2}{*}{ Variable (range) } & & \multicolumn{3}{|c|}{$\begin{array}{l}\text { Age group (20s-30s) } \\
\quad(N=417)\end{array}$} & \multicolumn{2}{|c|}{$\begin{array}{l}\text { Age group (40s-50s } \\
\qquad(N=412)\end{array}$} \\
\hline & & Mean & $S S D$ & & Mean & $S D$ \\
\hline \multicolumn{2}{|l|}{ Political efficacy ${ }^{a}(1-5)$} & 3.42 & 1.05 & & 3.56 & 0.73 \\
\hline \multicolumn{2}{|l|}{ Offline media use ${ }^{a}(1-4)$} & 2.52 & 0.97 & & 3.14 & 0.97 \\
\hline \multicolumn{2}{|l|}{ Online media use ${ }^{a}(1-4)$} & 3.01 & 0.97 & & 2.46 & 1.17 \\
\hline \multicolumn{2}{|l|}{ Offline communication ${ }^{a}(1-4)$} & 2.79 & 0.75 & & 3.02 & 0.82 \\
\hline \multicolumn{2}{|l|}{ Online communication (1-4) } & 1.33 & 0.85 & & 1.13 & 1.00 \\
\hline \multicolumn{7}{|l|}{ Political engagement $(0-1)$} \\
\hline \multicolumn{2}{|l|}{ Vote $^{\text {a }}$} & 0.72 & 0.38 & & 0.82 & 0.45 \\
\hline \multicolumn{2}{|l|}{ Signing petitions } & 0.25 & 0.43 & & 0.22 & 0.41 \\
\hline \multicolumn{2}{|l|}{ Social movements ${ }^{\mathrm{a}}$} & 0.17 & 0.31 & & 0.11 & 0.33 \\
\hline \multicolumn{2}{|c|}{ Demonstrations $\mathrm{a}^{\mathrm{a}}$} & 0.16 & 0.28 & & 0.09 & 0.31 \\
\hline \multicolumn{2}{|c|}{ Joining political parties/ civic groups } & 0.06 & 0.27 & & 0.08 & 0.25 \\
\hline \multicolumn{7}{|c|}{ 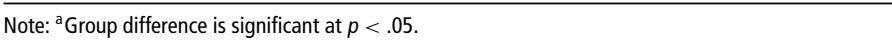 } \\
\hline \multicolumn{7}{|l|}{ Table 2} \\
\hline \multicolumn{7}{|c|}{ Correlations Among Study Variables Across Age Groups } \\
\hline \multicolumn{7}{|l|}{$40 s-50 s(N=412)$} \\
\hline $20 \mathrm{~s}-30 \mathrm{~s}(N=417)$ & 1 & 2 & 3 & 4 & 5 & 6 \\
\hline 1. Political efficacy & - & $.11 *$ & $.21 *$ & .01 & -.04 & $.22 *$ \\
\hline 2. Offline media use & .00 & - & $.28 *$ & .02 & .03 & $.13 *$ \\
\hline 3. Online media use & .06 & $.39 *$ & - & $.11 *$ & $.13 *$ & $.25 *$ \\
\hline 4. Offline communication & $.13 *$ & .05 & .02 & - & $.50 *$ & $.19 *$ \\
\hline 5. Online communication & .09 & $.10 *$ & $.14 *$ & $.43 *$ & - & $.14 *$ \\
\hline 6. Political engagement & $.25 *$ & .06 & $.11 *$ & $.17 *$ & $.11 *$ & - \\
\hline
\end{tabular}

\section{Testing the Mediational Models}

To assess the plausibility of the hypothesis that the relationship between media use and political engagement is mediated by communication, we tested two mediational models. The initial structural model (see Figure 1) reflecting partial mediation was specified with both direct and indirect paths from media use to political engagement via two mediators. The second structural model represented the full mediational model, which did not include direct effects of media use to political engagement.

Results indicated that different mediational models showed good fit for the two groups. For the 2030 generation, the full mediational model yielded a good fit to the sample: an overall $\chi^{2}(9)$ value of 81.84 , with CFI $=.946$ and RMSEA $=.064$; and the partial mediational model yielded a poor fit to the sample: an overall $\chi^{2}(7)$ value of 76.59, with CFI $=.628$ and RMSEA $=.157$. For the 4050 generation, the partial mediational model yielded a good fit to the sample; an overall $\chi^{2}(7)$ value of 29.99 , with $\mathrm{CFI}=.997$, and RMSEA $=.023$; and, in contrast, the full mediational model yielded a poor fit to the sample; an overall $\chi^{2}(9)$ value of 33.67 , with CFI $=.605$, and RMSEA $=.152$. Thus we chose the full mediational model as the final theoretical model for the 2030 generation while the partial mediational model was chosen as the final theoretical model for the 4050 generation. The fit of the final models was deemed acceptable in terms of three fit indices.
The standardised parameter estimates for final models are presented in Figure 2.

Maximum likelihood bootstrapping with a $95 \%$ confidence interval (see Shrout \& Bolger, 2002) was used to test whether there was a significant indirect effect from media use to political engagement through two mediating variables. After controlling the income and educational level, for the 2030 generation, results revealed that indirect (mediated) effects of online media use to political engagement via online communication was significant $(p$ $<.05)$. The largest path coefficient was from online media use to the mediator online communication $(\beta=.33)$. For the 4050 generation, results for direct effects indicated that online media use had significant meaningful effects on online communication and political engagement. The largest path coefficient was from online media use to political engagement in this group $(\beta=.44)$. Results from the mediating analyses revealed that none of indirect (mediated) effects of media use to political engagement via communication were significant for this age group. Political efficacy exerted a significant effect on online media use for both age groups ( $\beta=.10$ and .25 , respectively), but it only had a significant effect on offline media use for the 4050 generation $(\beta=.12)$.

\section{Discussion}

How political engagement can be enhanced is not an issue that only concerns South Korea. The continuous drop in 
Age group (20-30's)

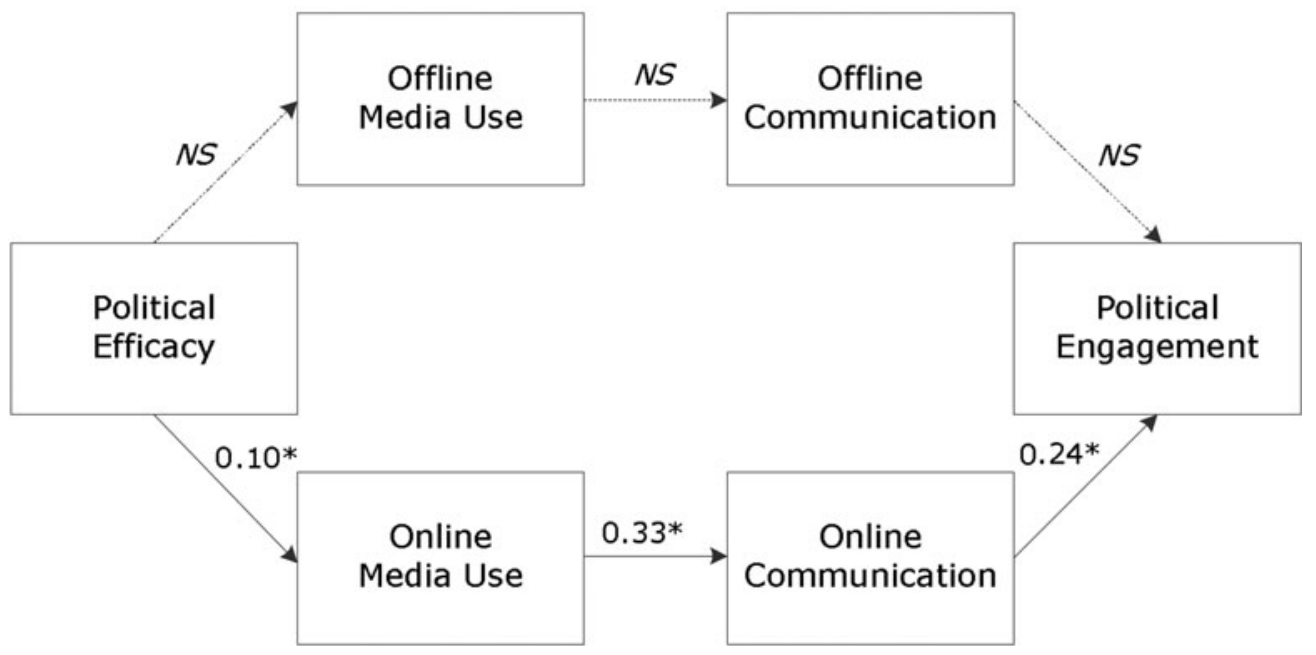

Age group (40-50's)

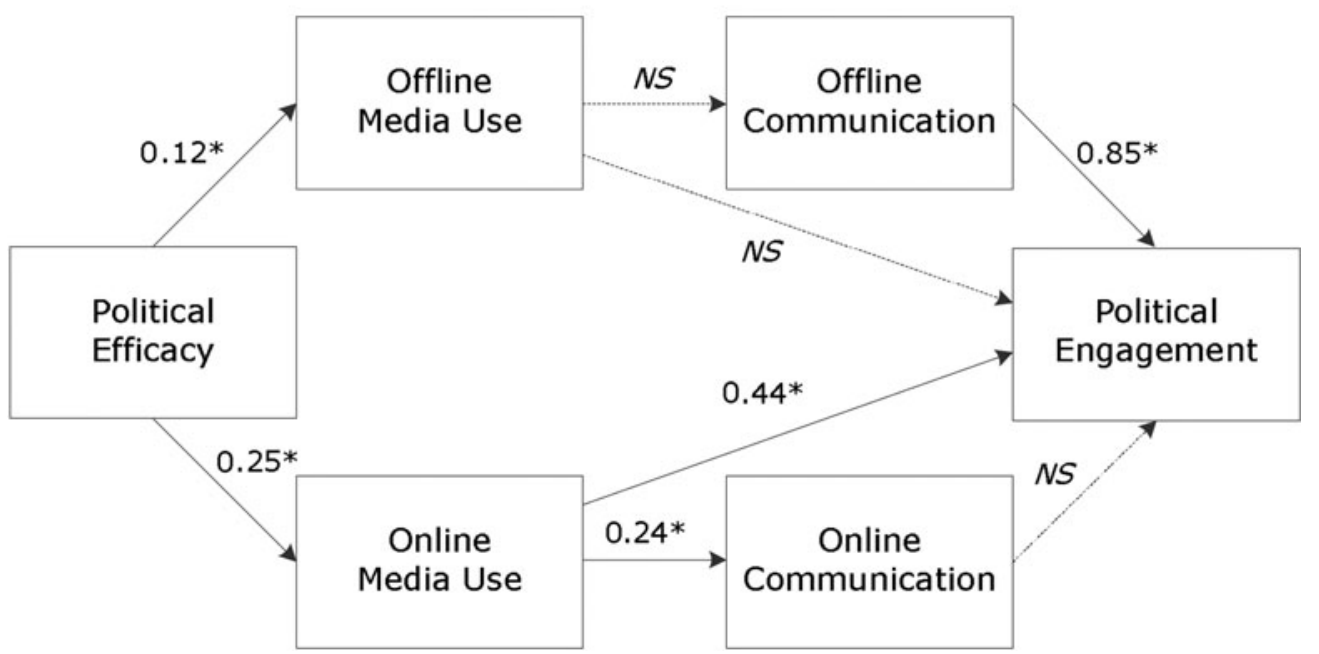

Figure 2

Final structural model with standardised solution.

Note: $* p<.05$; significant path coefficients are shown in bold line; NS $=$ non-significant.

rates of voting, a typical type of political engagement, has been a political issue in many countries, as well as a theme of academic research (Boulding, 2015; Mahler, Jesuit, \& Paradowski, 2014) because it is a sign of crisis for representative democracy. Thus, more attention is needed to investigate whether proactive utilisation of new media can increase political engagement (cf. Delli Carpini, 2000). In the long term, the focus is on the political landscape of representative democracy at the time of younger generations' entry into the electorates.

Our results demonstrate that the internal psychological factor of political efficacy is a significant predictor of whether people use and communicate through media (Moeller et al., 2013; Jung et al., 2011). Specifically, the 2030 generation did not show a significant association between political efficacy and media use, whereas the 4050 generation showed that their political efficacy had significant relations between both offline and online media use. For the 4050 generation, their past political experiences might inform their high levels of political efficacy, having been socialised by their belief that political change is possible by political engagement (Semetko \& Valkenburg, 1998). This works as an internal motive to use media for political information (Miller et al., 1980; Verba et al., 1995). However, the country's economic instability might make the 2030 generation assume fewer positive attitudes towards engagement with politics.

We found the two generational groups had different preferences for types of political engagement. The 4050 generation was interested in formal political engagement (voting) while the 2030 generation showed more interest in informal political engagement, such as social 
movements. The preference of the 2030 generation for informal political engagement implied that cultural experiences of their socialisation process (e.g., candlelight vigils, green products campaign) rather than formal political participation can have steadying effects on their political attitudes and political engagement. These findings provide evidence that socialisation circumstances are important in understanding types of political engagement.

Unique experiences of two generations are related to generational effects. In order to understand the issue of current political engagement, generational effects should be considered rather than the life cycle effect (Putnam, 2001). Differences between age groups who share similar experiences and attitudes (Mannheim, 1952) may have more explanatory power about why there are differences in political engagement than arbitrarily defined age group distinctions. It implies that each generation has a unique style of communication attributed from their socialisation process (cf. Bimber, 2001; Bennett, 2012).

Technological advances in media have altered the sources from which people obtain information and, in particular, have exerted an influence on the socialisation process of how the generations communicate. The present study revealed that the 2030 and the 4050 generations are different in their use of communication and online and offline media. The older age group was found to prefer offline media, whereas the younger group mostly used online media, as found in other studies (Oser et al., 2013; Pew Research Center, 2012). This supported the idea that the media environments in which people spent their young adulthood contribute to the types of media they mostly used. Additionally, these differences in how easily each generational group adopts new technology and the values held regarding that technology contribute to making communication between age groups more difficult (McLeod, 2000; Moeller et al., 2013; Hahm, 2002). Lack of communication across age groups may become a larger societal concern in the political realm.

As our research has shown, online media use had more direct effects on political engagement of the 4050 generation than the 2030 generation, showing that different media use influenced political engagement through different paths between the age groups. That is, people of this age group who used online media tended to be more active in participating in politics, and their online media use was strongly linked to their communication through online media. Specifically, the 4050 generation who had not been socialised in new media demonstrated positive connections between online media use and political engagement, which is in the same vein of the previous literature (de Zúñiga \& Valenzuela, 2011; Jung et al., 2011; Tian, 2011; Willnat et al., 2013). The fact that online media use is closely related to voluntary political engagement in this age group, who encountered this new type of media for the first time after adolescence, suggests that provision of political information through online media can encourage their political engagement and their polit- ical efficacy might exert indirect effects on their political engagement.

Among the 2030 generation, however, online media use did not directly affect their political engagement. Rather, online media use had an indirect influence via the mediation of online communication, echoing findings from other studies with different national samples (Moeller et al., 2013; McLeod, Shah, Hess, \& Lee, 2010). This group not only used online media more often than offline media, but also did not show significant paths towards political engagement through offline media. Online media use did not have direct connections to political engagement. Rather, their political engagement happened indirectly through communicating online with others. Therefore, communication through online media is needed to reach the 2030 generation with political information, but further research is needed to examine how this age group may be encouraged to go beyond communicating with others and actually participating more in politics.

Although an Australian election study showed that online communications are not as effective in mobilising offline political participation (Gibson \& McAllister, 2013), we cannot reject that online media use can promote a sense of solidarity among group members. In a study on participants in Hong Kong, online media use mediated the relationship between in-group identification and collective action, maintaining social identification with the group and strengthening willingness for collective actions (Chan, 2014). Also, according to an empirical study in Singapore, online bridging ties do not contribute to traditional political participation, but online bridging ties and online political engagement were linked with each other (Skoric,Ying, \& Ng, 2009).

While the current research revealed that the paths through which media use functions differently in predicting political engagement according to the two generational groups, the study was not without limitations. First, it did not consider people's evaluation of how they perceive online media. The analyses found that the 4050 generation relied less on online media than the 2030 generation did, but their use of online media had a more significant influence on their political engagement. Although such effects of media were apparent even after controlling for income and education levels, the analyses did not take into consideration whether the 4050 generation relied more on or had more favourable attitudes toward online media than the 2030 generation. One area of further research would be to examine not only media preferences, but also the value attributed to online and offline media. Second, the study was cross-sectional in nature, and therefore causal impacts of political efficacy, media use and communication, and political engagement cannot be claimed. Further research should examine these factors at multiple time points to determine this more conclusively. Another limitation of the study was that it does not answer how the different kinds of online communication contents might promote 
political engagement. With online media, people can see others' opinions and fierce debates on unfamiliar public issues. This may discourage some individuals from becoming involved. Communication with people having opposing opinions may impede one's political engagement (Hopmann, 2012; Mutz, 2002).

The main findings of this study imply that the activation of online media use and communication are not efficient strategies to promote political engagement by people in the 2030 generation. That is, merely relying on the universal use of and communication through online media does not enhance the level of political engagement among members of this generation. Rather, a viable alternative might be systemic civic education to build individuals' political efficacy (Jung et al., 2011; Meoller et al., 2013). Regardless of media use preferences and communication means, the study showed that attitudes of political efficacy had significant links to media use for both age groups, echoing studies conducted in other countries (Campbell et al., 1954; Morrell, 2003; Delli Carpini, 2004). Thus, the study provides additional factors we need to consider when attempting to solve low political participation and heighten political efficacy.

This relationship between media use and political engagement is echoed in other countries. The new democracies of Eastern Europe, like that of South Korea, experience generational differences in online communication and socialisation (McLeod, 2000). Additionally, the universalisation of online media in the United States can be a pivotal factor to change the political landscape when the younger generation reaches voting age (Xenos \& Moy, 2007). Considering the emergence of a digitally divided society, the older generations are more likely to be less active in accessing new media (Sylvester \& McGlynn, 2010), which means that the generational gap can become a greater societal issue in the long term.

\section{Acknowledgments}

This work was supported by the National Research Foundation of Korea Grant funded by the Korean Government (NRF-2013S1A3A2042859).

\section{References}

Ansolabehere, S., Iyengar, S., Simon, A., \& Valentino, N. (1994). Does attack advertising demobilize the electorate? American Political Science Reviews, 88, 829-838.

Asia Today. (2011, April 10). SNS, open new paradigm of politics. Retrieved from http://www.asiatoday.co.kr/view. php?key=468603

Bachmann, I., Kaufhold, K., Lewis, S.C., \& de Zúñiga, H.G. (2010). News platform preference: Advancing the effects of age and media consumption on political participation. International Journal of Internet Science, 5, 34-47.

Barnhurst, K.G. (2011). The new 'media affect' and the crisis of representation for political communication. International Journal of Press/Politics, 16, 573-593.
Bennett, W.L. (2012). The personalization of politics: Political identity, social media, and changing patterns of participation. The Annals of the American Academy, 644, 2039.

Bentler, P.M. \& Bonett, D.G. (1980). Significance tests and goodness of fit in the analysis of covariance structures. Psychological Bulletin, 88, 588-606.

Bentler, P.M. (1990). Comparative fit indices in structural models. Psychological Bulletin, 107, 238-246.

Berelson, B.R., Lazarsfeld, P.F., \& McPhee, W.N. (1954). Voting: A study of opinion formation in a presidential campaign. Chicago, IL: University of Chicago Press.

Bimber, B. (2001). Information and political engagement in America: The search for effects of information technology at the individual level. Political Research Quarterly, 54, 5367.

Blais, A., \& Dobrynska, A. (1998). Turnout in electoral democracies. European Journal of Political Research, 33, 239-261.

Brady, H.E., Verba, S., \& Schlozman, K.L. (1995). Beyond SES: A resource model of political participation. American Political Science Review, 89, 271-294.

Campbell, A., Gurin, G., \& Miller, W.E. (1954). The voter decides. Oxford, England: Row, Peterson, and Co.

Cha, F. (2013, November 27). 10 things South Korea does better than anywhere else. CNN.com. Retrieved December 10, 2014, from http://www.cnn.com/2013/11/27/trabel/ 10-things-south-korea-does-best/

Chan, M. (2014). Social identity gratifications of social network sites and their impact on collective action participation. Asian Journal of Social Psychology, 17, 229-235.

Chu, D. (2010). In search of presumption: Youth and the new media in Hong Kong. First Monday. Retrieved from http:// firstmonday.org/ojs/index.php/fm/article/view/2772/2451

Delli Carpini, M.X. (2000). Gen.com: Youth, civic engagement, and the new information environment. Political Communication, 17, 341-349.

Delli Carpini, M.X. (2004). Mediating democratic engagement: The impact of communication on citizens' involvement in political and civic life. In L.L. Kaid (Ed.), Handbook of Political Communication Research (pp. 395-434). Mahwah, NJ: Lawrence Erlbaum.

de Zúñiga, H.G., \& Valenzuela, S. (2011). Mediating path to a stronger citizenship: Online and offline networks, weak ties, and civic engagement. Communication Research, 38, 397421.

Downs, A. (1957). An economic theory of democracy. New York: Harper Row.

Ferri, P., (2012). Digital and inter-generational divide. In A. Cartelli (Ed.), Current trends and future practices for digital literacy and competence (pp.1-18). Hershey, PA \& London: Information Science Reference.

Gibson, R.K., \& McAllister, I. (2013). Online social ties and political engagement. Journal of Information Technology \& Politics, 10, 21-34.

Hahm, I. (2002). From generational conflict to generational harmonization. Thought, 12, 188-209. 
Henn, M., Weinstein, M., \& Wring, D. (2002). A generation apart? Youth and political participation in Britain. British Journal of Politics and International Relations, 4, 167-192.

Hopmann, D.N. (2012). The consequences of political disagreement in interpersonal communication: New insight from a comparative perspective. European Journal of Political Research, 51, 265-287.

Hooghe, M. (2004). Political socialization and the future of politics, Acta Politica, 39, 331-341.

Huntington, S.P. (1968). Political order in changing societies. New Haven and London: Yale University Press.

Ikeda, K., \& Boase, J. (2011). Multiple discussion networks and their consequence for political participation. Communication Research, 38, 660-683.

Jaeger, P.T., Bertot, J.C., \& Shilton, K. (2012). Information policy and social media: Framing government-citizen web 2.0 interactions. In C.G. Reddick \& S.K. Aikins (Eds.), Web 2.0 technologies and democratic governance (pp. 11-25). New York: Springer Science.

Jugert, P., Eckstein, K., Noack, P., Kuhn, A., \& Benbow, A. (2013). Offline and online civic engagement among adolescents and young adults from three ethnic groups. Journal of Youth Adolescence, 42, 123-135.

Jung, N., Kim, Y., \& de Zúñiga, H.G. (2011). The mediating role of knowledge and efficacy in the effects of communication on political participation. Mass Communication and Society, 14, 407-430.

Mahler, V.A., Jesuit, D.K., \& Paradowski, P.R. (2014). Electoral turnout and state redistribution: A cross-national study of fourteen developed Countries. Political Research Quarterly, 67, 361-373.

Mannheim, K. (1952). The problem of generations. In P. Kecskemeti (Ed.), Karl Mannheim: Essays (pp. 276-322). New York: Routledge.

McLeod, J.M. (2000). Media and civic socialization of youth. Journal of Adolescence of Health, 27, 45-51.

McLeod, D.M., Shah, D.V., Hess, D., \& Lee, N.J. (2010). Communication and education: Creating competence for socialization into public life. In L.R. Sherrod, J. Torney-Purta, \& C.A. Flanagan (Eds.), Handbook of civic engagement in youth (pp. 363-392). Hoboken, NJ: Wiley \& Sons.

Milbrath, L.W., \& Goel, M.L. (1977). Political participation: How and why do people get involved in politics? Chicago: Rand McNally.

Miller, W.E., Miller, A.H., \& Schneider, E.J. (1980). American national election studies data sourcebook: 1952-1978. Cambridge: Harvard University Press.

Moeller, J., de Vresse, C., Esser, F., \& Kunx, R. (2013). Pathway to political participation: The influence of Online and Offline news media on internal efficacy and turnout of first-time voters. American Behavioral Scientist, 58, 689-700.

Morrell, M.E. (2003). Survey and experimental evidence for a reliable and valid measure of internal political efficacy. The Public Opinion Quarterly, 67, 589-602.

Muthén, L., \& Muthén, B. (2010). Mplus user's guide. Los Angeles, CA: Muthén \& Muthén.
Mutz, D.C. (2002). The consequences of cross-cutting networks for political participation. American Journal of Political Science, $26,838-855$.

Nisbet, E.C., Stoycheff, E., \& Pearce, K.E. (2012). Internet use and democratic demands: a multinational, multilevel model of internet use and citizen attitudes about democracy. Journal of Communication, 62, 249-265.

Oser, J., Hooghe, M., \& Marien, S. (2013). Is online participation distinct from offline participation? A latent class analysis of participation types and their stratification. Political Research Quarterly, 66, 91-101.

Pew Research Center. (2012, October 19). Social media and political engagement. Retrieved from http://www.pewinternet. org/2012/10/19/social-media-and-political-engagement/

Putnam, R. (2001). The strange disappearance of civic America. The American Prospect, 24, 34-48.

Rosenstone, S.J., \& Hansen, J.M. (1993). Mobilization, participation, and democracy in America. New York, NY: Macmillan.

Schmitt-Beck, R. (2003). Mass communication, personal communication and vote choice: The filter hypothesis of media influence in comparative perspective. British Journal of Political Science, 33, 233-259.

Semetko, H.A., \& Valkenburg, P.M. (1998). The impact of attentiveness on political efficacy: Evidence from a three-year German panel study. International Journal of Public Opinion Research, 10, 195-210.

Shah, D.V., Cho, J., Nah, S., Gotlieb, M.R., Hwang, H., Lee, N., Scholl, R., \& McLeod, D. (2007). Campaign ads, online messaging, and participation: Extending the communication mediation model. Journal of Communication, 57, 676-703.

Shrout, P.E., \& Bolger, N. (2002). Mediation in experimental and non-experimental studies: New procedures and recommendations. Psychological Methods, 7, 422-445.

Skoric, M.M., Ying, D., \& Ng, Y. (2009). Bowling online, not alone: online social capital and political participation in Singapore. Journal of Computer-Mediated Communication, 14, 414-433.

Sotirovic, M., \& McLeod, J.M. (2001). Values, communication behavior, and political participation. Political Communication, 18, 273-300.

Steenkamp, J.E.M., \& Baumgartner, H. (1998). Assessing measurement invariance in cross-national consumer research. Journal of Consumer Research, 25, 78-107.

Steiger, J.H., \& Lind, J.M. (1980, May). Statistically based tests for the number of common factors. Paper presented at the Annual Meeting of the Psychometric Society, Iowa City, IA.

Sylverster, D.E., \& McGlynn, A.J. (2010). The digital divide, political participation, and place. Social Science Computer Review, $28,64-74$.

Tian, Y. (2011). Communication behaviors as mediators: Examining links between political orientation, political communication, and political participation. Communication Quarterly, 59, 380-394.

Tolbert, C.J., \& McNeal, R.S. (2003). Unraveling the effects of the internet on political participation. Political Research Quarterly, 56, 175-185. 
Valenzuela, S., Kim, Y., \& de Zúñiga, H.G. (2012). Social networks that matter: Exploring the role of political discussion for online political participation. International Journal of Public Opinion Research, 24, 163-184.

Verba, S., \& Nie, N.H. (1972). Participation in America. New York: Harper \& Row.

Verba, S., Schlozman, K.L., \& Brady, H.E. (1995). Voice and equality: Civic voluntarism in American politics. Cambridge, MA: Harvard University Press.

Watts, M.W. (1999). Are there typical age curves in political behavior? The 'age invariance' hypothesis and political socialization. Political Psychology, 20, 477-299.
Willnat, L., Wong, W.J., Tamam, E., \& Annette, A. (2013). Online media and political participation: The case of Malaysia. Mass Communication and Society, 16, 557585.

Wolfinger, R.E., \& Rosenstone, S.J. (1980). Who votes? New Haven, CT: Yale University Press.

Xenos, M. \& Moy, P. (2007). Direct and differential effects of the internet on political and civic engagement. Journal of Communication, 57, 704-718.

Ye, W.M., Sarrica, M., \& Fortunati, L. (2014). Two selves and online forums in China. Asian Journal of Social Psychology, $14,1-11$. 